\title{
Selection of Environmentally Friendly Solvents for the Extravehicular Mobility Unit Secondary Oxygen Pack Cold Trap Testing
}

\author{
John Steele ${ }^{1}$ and Jesse Morenz ${ }^{2}$ \\ Hamilton Sundstrand, Windsor Locks, CT, 06096 \\ Cinda Chullen ${ }^{3}$ and Curtis Stephenson ${ }^{4}$ \\ NASA/JSC, Houston, TX, 77058
}

\begin{abstract}
Freon-113® has been used as a chemistry lab sampling solvent at NASA/JSC for EMU (Extravehicular Mobility Unit) SOP (Secondary Oxygen Pack) oxygen testing Cold Traps utilized at the USA (United Space Alliance) Houston facility. Similar testing has occurred at the HSWL (Hamilton Sundstrand Windsor Locks) facility. A NASA Executive Order banned the procurement of all ODS (ozone depleting substances), including Freon-113® by the end of 2009. In order to comply with NASA direction, HSWL began evaluating viable solvents to replace Freon-113®. The study and testing effort to find Freon- $113 \otimes$ replacements used for Cold Trap sampling is the subject of this paper.

Test results have shown HFE-7100® (a 3M fluorinated ether) to be an adequate replacement for Freon-113® as a solvent to remove and measure the non-volatile residue collected in a Cold Trap during oxygen testing. Furthermore, S-316® (a Horiba Instruments Inc. high molecular weight, non-ODS chlorofluorocarbon) was found to be an adequate replacement for Freon-113 ${ }^{\circledR}$ as a solvent to reconstitute non-volatile residue removed from a cold trap during oxygen testing for subsequent HC (hydrocarbon) analysis via FTIR (Fourier Transform Infrared Spectroscopy).
\end{abstract}

\section{Nomenclature}

$\begin{array}{lll}\mathrm{mg} & = & \text { milligram } \\ \mathrm{mL} & = & \text { milliliter } \\ \text { TLV } & = & \text { Threshold Limit Value } \\ \text { OSHA }= & \text { Occupational Health and Safety Administration } \\ \text { GWP }= & \text { Global Warming Potential } \\ \text { FTIR } & = & \text { Fourier Transform Infrared Spectroscopy } \\ \text { HC } & = & \text { hydrocarbon } \\ \text { FC } & = & \text { fluorocarbon } \\ \text { EMU } & = & \text { Extra Vehicular Mobility Unit } \\ \text { SOP } & = & \text { Secondary Oxygen Pack } \\ \text { ODS }= & \text { Ozone Depleting Substance } \\ \text { NVR }= & \text { Non Volatile Residue } \\ \text { PPE }= & \text { Personal Protective Equipment } \\ \text { ppm }= & \text { parts per million }\end{array}$

${ }^{1}$ Fellow, Materials Engineering, 1 Hamilton Rd. Windsor Locks, CT 06096 M/S 1A-2-W62, professional ${ }^{2}$ Chemist, Materials Engineering, 1 Hamilton Rd. Windsor Locks, CT 06096 M/S 1A-2-W62, professional ${ }^{3}$ Project Engineer, Space Suit and Crew Survival Systems Branch, Crew and Thermal Systems Division, 2101 NASA Parkway, Houston, TX 77058/EC5, professional

${ }^{4}$ EMU Hardware Manager, EVA Operations, EVA Office, 2101 NASA Parkway, Houston, TX 77058/XO, professional 


\section{Overview}

Freon-113® is used as a sampling solvent at NASA/JSC for EMU (extravehicular Mobility Unit) SOP (Secondary Oxygen Pack) oxygen testing Cold Traps utilized at the USA (United Space Alliance) Houston facility. Similar testing occurs at the HSWL (Hamilton Sundstrand Windsor Locks) facility. A NASA Executive Order banned the procurement of all ODS (ozone depleting substances), including Freon-113 $®$ by the end of 2009. HSWL was directed per EV $2241 \mathrm{H} 00 \mathrm{~K}$ to evaluate and certify a replacement for Freon-113® for the Cold Trap sampling process. The intent of this paper is to detail the results of the evaluation and certification process.

\section{Test Plan}

A number of people from pertinent disciplines (chemistry, test engineering, materials \& processes, environmental health \& safety and project engineering) at HSWL, HSMS, NASA/JSC, NASA/WSTF and USA took part in the development of a Test Plan to evaluate replacements for Freon-113 $B$ Cold Trap sampling. A Test Plan Flow Chart was developed (see Diagram 1) to facilitate the activities associated with this effort.

Preliminary work focused on the development of a soiling model to represent contaminates observed in Cold Traps on a routine basis. Five alternate solvents were initially selected two replacement approaches that were to undergo more detailed soil challenge testing. The results of successful detailed soil challenge testing were then compared and contrasted to similar results obtained with Freon-113®.

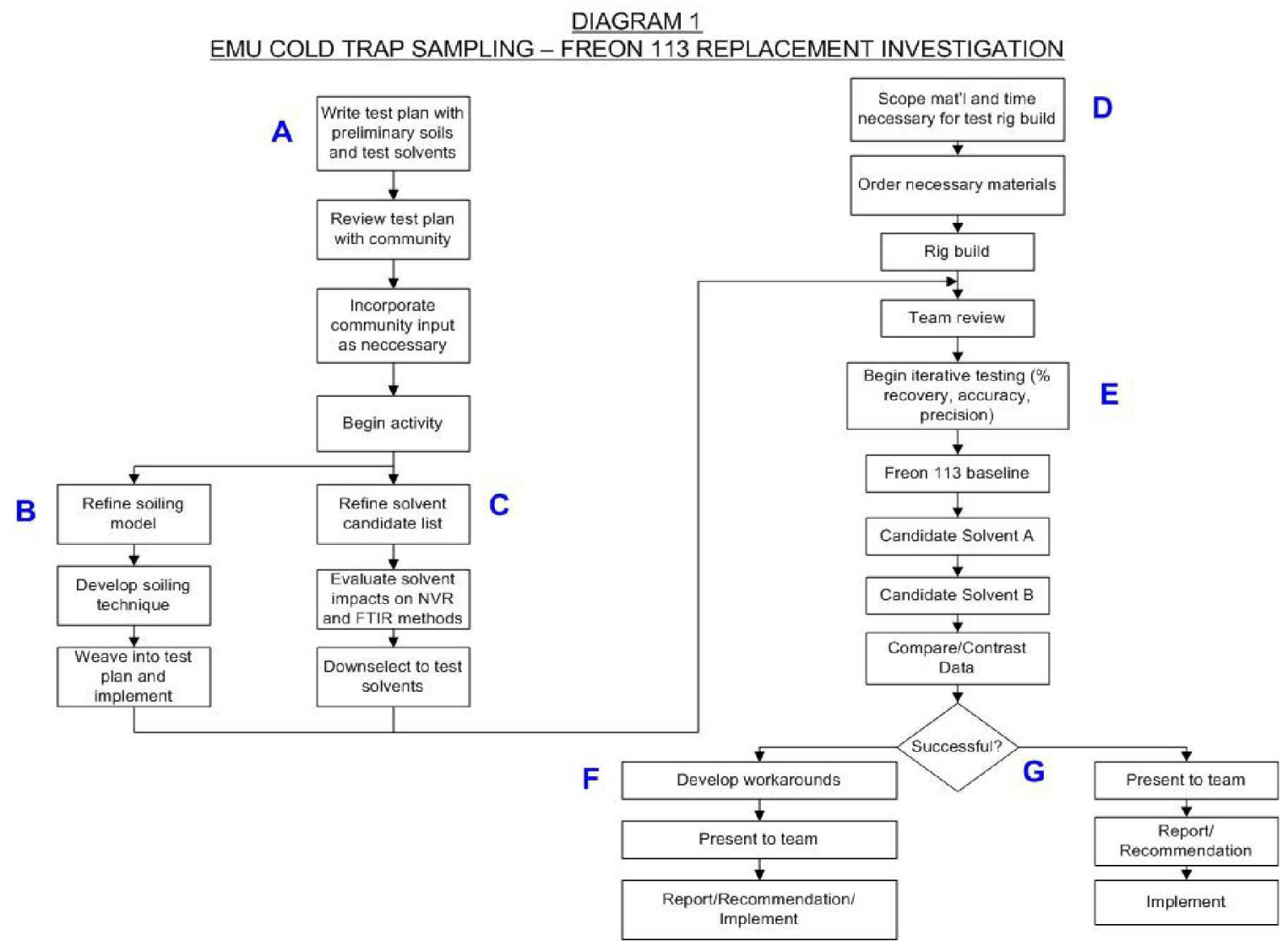


The key elements of this Test Plan are shown In Diagram 1 and are categorized as follows:

- Test Plan Preparation and Review - A test plan was prepared and reviewed with the One EVA community, including Hamilton Sundstrand Windsor Locks and Houston, USA Houston and NASA/JSC. The Test Plan incorporated input from the One EVA community prior to implementation. This activity is identified by the letter "A" in Diagram 1 of this paper.

- Soiling Model Definition - A soiling model was developed and was utilized to test the efficacy of the candidate alternate solvents evaluated in this study. This activity is identified by the letter " $\mathrm{B}$ " in Diagram 1 of this paper.

- Candidate Solvent Selection - Selection criteria were applied to a list of candidate solvents to narrow the list of solvents to be fully evaluated in the course of this study. This activity is identified by the letter "C" in Diagram 1 of this paper.

- Test Rig Build - A test rig that simulates the way in which Freon-113® is utilized for Cold Trap sampling was built. This activity is identified by the letter " $\mathrm{D}$ " in Diagram 1 of this paper.

- Soil Recovery Sampling - Each of the two current Cold Trap sampling approaches (the one conducted at HSWL is more automated and varies from the more manually-intensive approach used at NASA/JSC) were conducted on Cold Traps purposely soiled with the soiling model that was developed. Subsequent solvent sampling to determine percent recovery, accuracy, precision and lower level of detection for each of the candidate solvents that were selected was conducted thereafter. This activity is identified by the letter " $\mathrm{E}$ " in Diagram 1 of this paper.

- Data Consolidation and Recommendation - The data acquired as a result of the testing was consolidated and utilized to formulate the recommended approach to phase-out the use of Freon-113 for EMU Cold Trap testing at the NASA/JSC site.

\section{Methods and Materials/Results}

\section{A. Soiling Model Definition, Addition Technique and Recovery Methodology}

A historical data review was conducted. The review included data from the initial EMU SOP Regulator contamination episode in the year 2000 , the soiling model development work conducted during the HSWL phaseout of Freon-113 as a precision cleaning solvent, and historical results from actual Cold Trap sampling.

A methodology was developed to quantitatively transfer model soils to test Cold Traps. This methodology was standardized to ensure the repeatability of the soiling of Cold Traps in this testing. The methodologies used at HSWL and NASA/JSC were reviewed and since they varied somewhat, both were adopted as means utilized to recover soils during this study. The HSWL methodology was used initially to evaluate the alternate candidates. Both methodologies were used thereafter for the final selected alternate candidate.

A mixture of mineral oil to represent hydrocarbons (hereafter denoted as $\mathrm{HC}$ ) and the fluorinated oil used in Krytox® to represent fluorocarbon (hereafter denoted as FC) were utilized as the soil mixture in this study.

\section{B. Candidate Replacement Solvent Selection}

A set of criteria were developed to evaluate candidate solvents to replace Freon-113® for the Cold Trap sampling application. Some solvents were eliminated outright due to gross non-compliance with the set criteria. A total of five underwent a full assessment to the established criteria. They are identified as Vertrel MCA®, HFE-7100®, trichloroethylene, tetrachloroethylene and S-316®.The set of criteria that were evaluated are as follows:

- Ozone Depleting Character - Class I ODS solvents were ruled out. Class II or greater ODS were considered, though a complete lack of ozone depleting character was considered a positive. 
- Solvency of Model Soils - The candidate solvents were judged as to their ability to solvate the soil model. Some testing was conducted to acquire the evaluation data. Some of the data was acquired though literature search or vendor inquiry.

- Low Background NVR (Non Volatile Residue) - The background NVR of the candidate solvents was considered as to not interfere with the NVR determination that is conducted as one of the two Cold Trap assays. The target was the ability to determine a sensitivity of $0.1 \mathrm{mg}$ NVR in a sample from the candidate solvent background. Some testing was conducted to acquire the evaluation data. Some of the data was acquired though literature search or vendor inquiry.

- Low Infrared Absorbance at $2920 \mathrm{~cm}^{-1}$. The candidate solvents had to demonstrate a low infrared absorbance in the $2920 \mathrm{~cm}^{-1}$ range as to not interfere with the $\mathrm{HC}$ determination that is conducted as one of the two Cold Trap assays. The target was the ability to determine a sensitivity of $0.008 \mathrm{mg}$ hydrocarbon in a sample from the candidate solvent background. Some testing was conducted to acquire the evaluation data. Some of the data was acquired though literature search or vendor inquiry.

- Low OSHA Threshold Limit Value (TLV) - The candidate solvents shall be judged as to their relative OSHA TLV, and the ability to work with the solvents safely with standard PPE (personnel protective equipment).

- Low Global Warming Potential (GWP) - The candidate solvents were judged as to their relative GWP. The findings of this evaluation are summarized in Table 1. Data highlighted in Green is considered a "good" finding. Date highlighted in red is considered a "bad" finding. 
Table 1

Solvent Evaluation Against Criteria

\begin{tabular}{|c|c|c|c|c|c|c|}
\hline Criteria & $\begin{array}{l}\text { Vertrel } \\
\text { MCAB }\end{array}$ & $\begin{array}{l}\text { HFE } \\
7100 \otimes\end{array}$ & $\begin{array}{l}\text { Trichloro- } \\
\text { ethylene }\end{array}$ & $\begin{array}{c}\text { Tetrachloro- } \\
\text { ethylene }\end{array}$ & S-316\& & $\begin{array}{c}\text { Freon- } \\
113 \otimes\end{array}$ \\
\hline $\begin{array}{c}\text { SUMMARY } \\
\rightarrow\end{array}$ & $\begin{array}{c}\text { BAD FOR } \\
\text { NVR } \\
\text { BAD FOR } \\
\text { FTIR } \\
\text { BAD FOR } \\
\text { REACTOR } \\
\text { FINAL } \\
\text { FLUSH }\end{array}$ & $\begin{array}{c}\text { GOOD FOR } \\
\text { NVR } \\
\text { BAD FOR } \\
\text { FTIR } \\
\text { GOOD FOR } \\
\text { REACTOR } \\
\text { FINAL } \\
\text { FLUSH }\end{array}$ & $\begin{array}{c}\text { BAD FOR } \\
\text { NVR } \\
\text { BAD FOR } \\
\text { FTIR } \\
\text { BAD FOR } \\
\text { REACTOR } \\
\text { FINAL } \\
\text { FLUSH }\end{array}$ & $\begin{array}{l}\text { GOOD FOR } \\
\text { NVR } \\
\text { GOOD FOR } \\
\text { FTIR } \\
\text { BAD FOR } \\
\text { REACTOR } \\
\text { FINAL FLUSH }\end{array}$ & $\begin{array}{c}\text { BAD FOR } \\
\text { NVR } \\
\text { GOOD FOR } \\
\text { FTIR } \\
\text { BAD FOR } \\
\text { REACTOR } \\
\text { FINAL } \\
\text { FLUSH }\end{array}$ & $\begin{array}{c}\text { GOOD FOR } \\
\text { NVR } \\
\text { GOOD FOR } \\
\text { FTIR } \\
\text { GOOD FOR } \\
\text { REACTOR } \\
\text { FINAL FLUSH }\end{array}$ \\
\hline $\begin{array}{c}\text { Class I or II } \\
\text { ODS? }\end{array}$ & No & No & No & No & No & Yes \\
\hline $\begin{array}{c}\text { Initial } \\
\text { Solvency } \\
\text { Data Review } \\
\text { (HC \& FC) }\end{array}$ & $\begin{array}{c}\mathrm{HC}- \\
\text { Excellent } \\
\mathrm{FC}- \\
\text { Excellent }\end{array}$ & $\begin{array}{c}\mathrm{HC}-\mathrm{Good} \\
\text { (light HC) } \\
\text { FC - } \\
\text { Excellent }\end{array}$ & $\begin{array}{c}\mathrm{HC}- \\
\text { Excellent } \\
\text { FC - Good }\end{array}$ & $\begin{array}{c}\text { HC - Excellent } \\
\text { FC - Good }\end{array}$ & $\begin{array}{c}\mathrm{HC}- \\
\text { Excellent } \\
\mathrm{FC}-\text { Good }\end{array}$ & $\begin{array}{c}\mathrm{HC}- \\
\text { Excellent } \\
\mathrm{FC}-\text { Good }\end{array}$ \\
\hline $\begin{array}{c}\text { Background } \\
\text { NVR } \\
\text { (pre- } \\
\text { distillation) } \\
\end{array}$ & $\begin{array}{c}0.77 \mathrm{mg} / 100 \\
\mathrm{ml}\end{array}$ & $\begin{array}{c}<0.01 \\
\mathrm{mg} / 100 \mathrm{ml}\end{array}$ & $\begin{array}{c}0.54 \mathrm{mg} / 100 \\
\mathrm{ml}\end{array}$ & $\begin{array}{c}0.24 \mathrm{mg} / 100 \mathrm{ml} \\
\text { (borderline) }\end{array}$ & $\begin{array}{c}680 \mathrm{mg} / 100 \\
\mathrm{ml} \\
\text { (appears to } \\
\text { decompose) }\end{array}$ & $\begin{array}{c}<0.01 \mathrm{mg} / 100 \\
\mathrm{ml}\end{array}$ \\
\hline $\begin{array}{l}\text { Background } \\
\text { IR at } 2920 \\
\mathrm{~cm}-1 \text { (pre- } \\
\text { distillation) }\end{array}$ & $\begin{array}{l}\text { Totally } \\
\text { masks }\end{array}$ & $\begin{array}{c}\text { High } \\
\text { background }\end{array}$ & $\begin{array}{c}\text { High } \\
\text { background }\end{array}$ & $\begin{array}{c}\text { Minimal } \\
\text { background }\end{array}$ & $\begin{array}{c}\text { Minimal } \\
\text { background }\end{array}$ & $\begin{array}{c}\text { Minimal } \\
\text { background }\end{array}$ \\
\hline $\begin{array}{l}\text { Background } \\
\text { NVR } \\
\text { (post- } \\
\text { distillation) }\end{array}$ & $\begin{array}{c}0.38 \mathrm{mg} / 100 \\
\text { ml } \\
\text { Still too high, } \\
\text { but } \\
\text { distillation } \\
\text { shows } \\
\text { promise - } \\
\text { but adds } \\
\text { significant } \\
\text { time }\end{array}$ & $\begin{array}{l}<0.01 \\
\mathrm{mg} / 100 \mathrm{ml}\end{array}$ & $\mathrm{N} / \mathrm{A}$ & N/A & $\begin{array}{l}\text { Not done. } \\
\text { (appears to } \\
\text { decompose) }\end{array}$ & $\mathrm{N} / \mathrm{A}$ \\
\hline $\begin{array}{c}\text { Background } \\
\text { IR } \\
\text { At } 2920 \mathrm{~cm}-1 \\
\text { (post- } \\
\text { distillation) }\end{array}$ & $\begin{array}{c}\text { Totally } \\
\text { masks. } \\
\text { CH stretch } \\
\text { inherent in } \\
\text { the base } \\
\text { molecule. }\end{array}$ & $\begin{array}{c}\text { High } \\
\text { background. } \\
\text { CH stretch } \\
\text { inherent in } \\
\text { the base } \\
\text { molecule } \\
\end{array}$ & $\begin{array}{c}\text { High } \\
\text { background. } \\
\mathrm{CH} \text { stretch } \\
\text { inherent in the } \\
\text { base } \\
\text { molecule } \\
\end{array}$ & N/A & N/A & N/A \\
\hline OSHA TLV & 200 ppm & 600 ppm & $\begin{array}{c}50 \mathrm{ppm} \\
\text { JSC restricted } \\
\text { material list - } \\
\text { want to } \\
\text { minimize use } \\
\text { volume. } \\
\text { Reactor use } \\
\text { undesirable. }\end{array}$ & $\begin{array}{c}25 \text { ppm } \\
\text { JSC restricted } \\
\text { material list - } \\
\text { want to minimize } \\
\text { use volume. } \\
\text { Reactor use } \\
\text { undesirable. }\end{array}$ & $\begin{array}{c}\text { Not } \\
\text { Established } \\
\text { (health rating } \\
=1 \text { ) } \\
1=\text { minimal } \\
\text { concern }\end{array}$ & 1000 ppm \\
\hline $\begin{array}{c}\text { GWP } \\
\text { (relative to } \\
\text { CO2) }\end{array}$ & 806 & 397 & 9 & 9 & $\begin{array}{c}\text { Not } \\
\text { Established } \\
\text { (low VP 10 } \\
\text { mm Hg) }\end{array}$ & 6000 \\
\hline
\end{tabular}


Two of the candidate solvents (Vertrel MCA $®$ and trichloroethylene) were ruled out for any further consideration. Both had relatively high background NVR levels $(0.77 \mathrm{mg} / 100 \mathrm{~mL}$ and $0.54 \mathrm{mg} / 100 \mathrm{~mL}$ respectively), making them poor candidates for the Cold Trap flush role of a replacement solvent. Furthermore, each exhibited significant absorbance in the $2920 \mathrm{~cm}^{-1}$ wave number region of the infrared spectrum, making them poor candidates for the $\mathrm{HC}$ analysis via FTIR role of a replacement solvent.

HFE-7100® exhibited a very low NVR of $<0.01 \mathrm{mg} / 100 \mathrm{~mL}$, making it an excellent choice as a Cold Trap flush coolant. HSWL testing and supplier literature review indicated that HFE-7100® is an excellent solvent for FC soils and a reasonably good solvent for the lower boiling $\mathrm{HC}$ expected to migrate in a gas stream. Furthermore, HFE$7100 \circledast$ is deemed an oxygen compatible solvent by the NASA/WSTF and is recommended for the precision cleaning of high pressure oxygen components. Finally, HFE- $7100 囚$ has additional positive attributes such as a relatively high OSHA TLV (Threshold Limit Value) of 600ppm, and a relatively low GWP (Global Warming Potential) of 397. The one shortfall of HFE-7100® is the absorbance that it exhibits in the $2920 \mathrm{~cm}^{-1}$ wave number region of the infrared spectrum, making it a poor candidate for the $\mathrm{HC}$ analysis via FTIR role of a replacement solvent.

S-316 $\AA^{8}$ exhibited a very high NVR of $680 \mathrm{mg} / 100 \mathrm{~mL}$, making it a poor choice as a Cold Trap flush coolant. HSWL testing and supplier literature review indicated that S-316® is an excellent solvent for FC soils and for the lower boiling HC expected to migrate in a gas stream. S-316® has additional positive attributes such as a low health rating of " 1 " and a relatively low GWP (Global Warming Potential) due to its very low vapor pressure. The greatest benefit of S-316@ is the fact that it exhibits minimal absorbance in the $2920 \mathrm{~cm}^{-1}$ wave number region of the infrared spectrum, making it an excellent candidate for the HC analysis via FTIR role of a replacement solvent.

Tetrachloroethylene exhibited a fairly low NVR of $0.24 \mathrm{mg} / 100 \mathrm{~mL}$ and is known to be a good solvent for FC and HC. It was therefore deemed a reasonable Cold Trap flush coolant from a contaminant removal perspective. Unfortunately, tetrachloroethylene has a very low OSHA TLV of $25 \mathrm{ppm}$, making the possibility of leaving a trace amount in a component to be used in a closed human breathing loop a significant detriment. Tetrachloroethylene exhibits a minimal absorbance in the $2920 \mathrm{~cm}^{-1}$ wave number region of the infrared spectrum, making it an excellent candidate for the HC analysis via FTIR role of a replacement solvent. It falls second to S-316® in this regard though, again due to its relatively low OSHA TLV of $25 \mathrm{ppm}$ and the fact that it's listed as restricted material at NASA/JSC, to be used in small quantities as necessary only.

It became apparent after this exercise that no single candidate replacement solvent fulfilled all of the requirements expressed in the selection criteria. The best option appeared to be to utilize a dual solvent approach, HFE-7100® for the Cold Trap flush and NVR determination role, and S-316® to reconstitute the NVR for subsequent HC determination via FTIR. Two approaches to this dual solvent approach were targeted for full evaluation as follows:

\section{Option \#1}

A "nominal" Cold Trap flush with HFE-7100® utilizing the same flush methodology utilized by NASA/JSC (the more manually oriented approach) and HSWL (the more automated approach) was chosen as the primary approach. After collection of HFE-7100® from the Cold Trap, it was boiled down for an NVR determination. After NVR determination, the resultant residue was thereafter reconstituted with S-316® for subsequent HC determination via FTIR.

\section{Option \#2}

If Option \#1 were deemed to be unacceptable, and Option \#2 was planned, with focus on the one concern with the use of HFE-7100® Cold Trap flush; namely the potential that HFE-7100® would not be an adequate solvent for the HC fraction of the soil under evaluation. If that were the case, a "hybrid" flush of the Cold Trap was planned where variants of the nominal approach (such as multiple flushes, the incorporation of heat, or/and the incorporation of ultrasonic agitation) would be evaluated. As it turns out, Option \#1 was shown to be adequate as a replacement for Freon-113® for the Cold Trap sampling process, and efforts to evaluate Option \#2 were unnecessary. 


\section{Candidate Replacement Solvent Testing}

Option \#1 underwent a detailed evaluated as a replacement for Freon-113®. Cold Traps were purposely soiled with a 4-point range of soil mixtures as follows:

- $\quad 0.2 \mathrm{mg}$ NVR total, $0.01 \mathrm{mg} \mathrm{HC}$, balance FC

- $\quad 0.5 \mathrm{mg}$ NVR total, $0.05 \mathrm{mg} \mathrm{HC}$, balance FC

- 1.0mg NVR total, $0.10 \mathrm{mg} \mathrm{HC}$, balance FC

- 5.0mg NVR total, $0.50 \mathrm{mg} \mathrm{HC}$, balance FC

After the introduction of each of these soil mixtures into a Cold Trap, each of the two sampling processes (HSWL automated and NASA/JSC manual) were conducted in triplicate to determine percent recovery, accuracy, precision and sensitivity with the use of Freon-113® as a baseline, then with the use of the Option \#1 scheme. The target was the acquisition of results that were equal to or better than those obtained with Froen-113®, but the acceptance of results as "successful" would be subject to One EVA community review and discussion.

Diagram 2 is a representation of the sampling apparatus used for the Cold Trap flushing procedure conducted as HSWL. Tables $2,3,4,5$ and 6 contain the data obtained in the course of the testing as previously described.

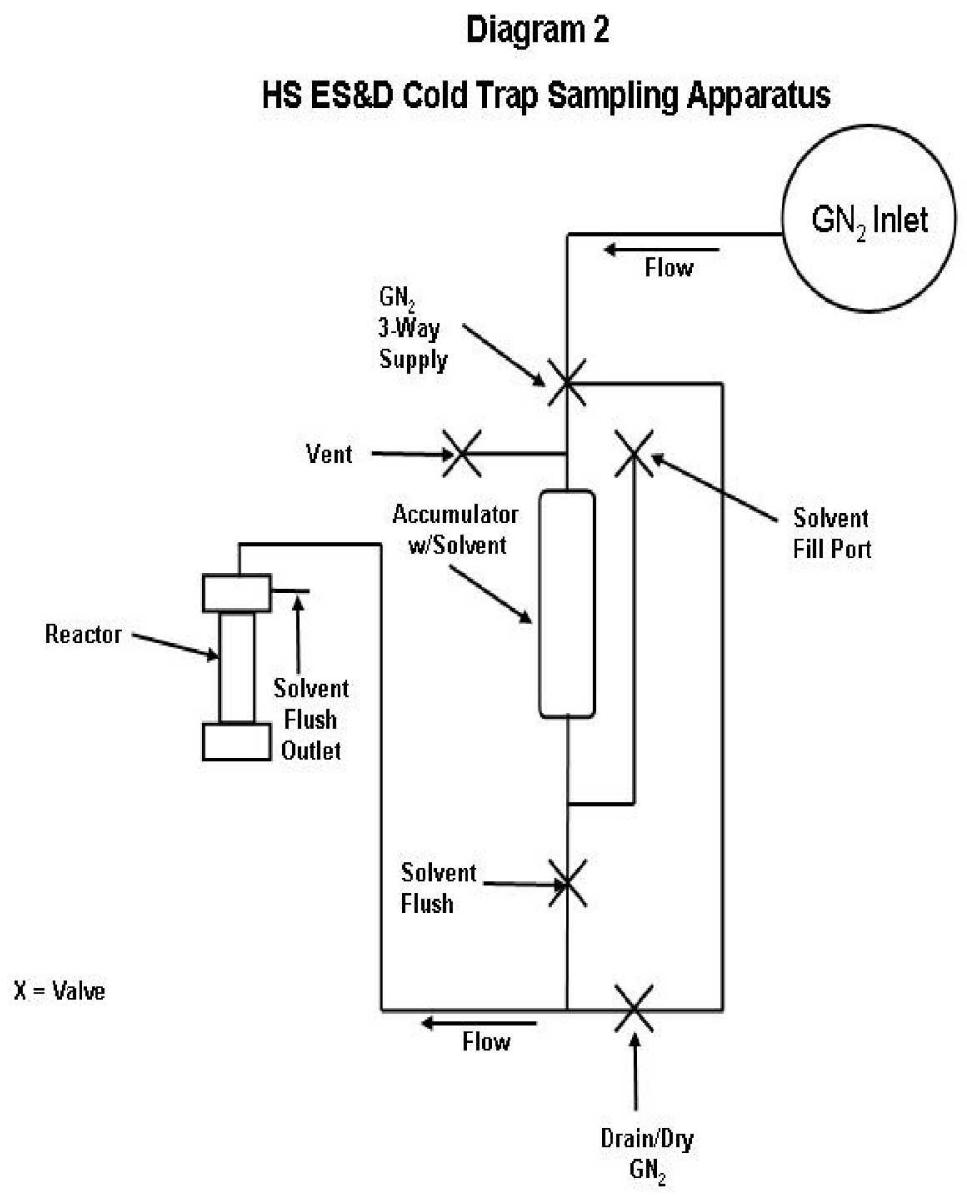


Table 2

Freon-113® Baseline Process - HSWL Methodology

\begin{tabular}{|ccccc|}
\hline Freon 113®/Freon 113® & \multicolumn{5}{c|}{ NVR/HC Recovery: Hamilton Method } \\
\hline Soil: FC/HC (mg) & Replicate 1 & Replicate 2 & Replicate 3 & Avg. \% Recovery \\
& & & & $\mathbf{9 0 / 8 0 \%}$ \\
$\mathbf{0 . 1 0 0 / 0 . 0 1 0}$ & $0.090 / 0.008$ & $0.070 / 0.008$ & $0.100 / 0.008$ & $\mathbf{9 3 / 9 3 \%}$ \\
$\mathbf{0 . 5 0 0 / 0 . 0 5 0}$ & $0.500 / 0.050$ & $0.420 / 0.040$ & $0.480 / 0.050$ & $\mathbf{9 9 / 8 3 \%}$ \\
$\mathbf{1 . 0 0 / 0 . 1 0 0}$ & $1.00 / 0.080$ & $1.0 / 0.080$ & $0.990 / 0.090$ & $\mathbf{9 8 / 8 8 \%}$ \\
$\mathbf{5 . 0 0 / 0 . 5 0 0}$ & $5.00 / 0.440$ & $5.0 / 0.400$ & $4.62 / 0.480$ & \\
\hline
\end{tabular}

Table 3

Freon-113® Baseline Process - NASA/JSC Methodology

\begin{tabular}{|c|c|c|c|c|}
\hline Freon $113 \otimes /$ Freon $113 \otimes$ & \multicolumn{4}{|c|}{ NVR/HC Recovery: JSC Method } \\
\hline Soil: FC/HC (mg) & Replicate 1 & Replicate 2 & Replicate 3 & Avg. \% Recovery \\
\hline $0.200 / 0.020$ & $0.190 / 0.020$ & $0.200 / 0.020$ & $0.200 / 0.020$ & $98 / 100 \%$ \\
\hline $0.500 / 0.050$ & $0.500 / 0.050$ & $0.490 / 0.050$ & $0.500 / 0.050$ & $99 / 100 \%$ \\
\hline $1.00 / 0.100$ & $1.00 / 0.100$ & $1.00 / 0.100$ & $1.00 / 0.100$ & $100 / 100 \%$ \\
\hline $5.00 / 0.500$ & $4.68 / 0.410$ & $4.72 / 0.430$ & $4.62 / 0.450$ & $94 / 86 \%$ \\
\hline \multicolumn{5}{|c|}{$\begin{array}{c}\text { Table } 4 \\
\text { HFE-7100® NVR - HSWL Methodology }\end{array}$} \\
\hline HFE $7100 \circledast /$ Freon $113 \otimes$ & \multicolumn{4}{|c|}{ NVR/HC Recovery: Hamilton Method } \\
\hline Soil: FC/HC (mg) & Replicate 1 & Replicate 2 & Replicate 3 & Avg. \% Recovery \\
\hline $0.200 / 0.020$ & $0.200 / 0.0150$ & $0.200 / 0.020$ & $0.200 / 0.020$ & $100 / 92 \%$ \\
\hline $0.500 / 0.050$ & $0.500 / 0.049$ & $0.500 / 0.050$ & $0.500 / 0.050$ & $100 / 99 \%$ \\
\hline $1.00 / 0.100$ & $0.990 / 0.088$ & $1.00 / 0.081$ & $0.910 / 0.087$ & $97 / 85 \%$ \\
\hline $5.00 / 0.500$ & $5.00 / 0.312$ & $4.76 / 0.400$ & $4.79 / 0.380$ & $97 / 73 \%$ \\
\hline
\end{tabular}


Table 5

HFE-7100® NVR / S-316® HC - HSWL Methodology

\begin{tabular}{|ccccc|}
\hline HFE 7100®/S-316® & \multicolumn{3}{c|}{ NVR/HC Recovery: Hamilton Method } \\
\hline Soil: FC/HC (mg) & Replicate 1 & Replicate 2 & Replicate 3 & Avg. \% Recovery \\
& & & & \\
$\mathbf{0 . 2 0 0 / 0 . 0 2 0}$ & $0.200 / 0.016$ & $0.200 / 0.014$ & $0.200 / 0.015$ & $\mathbf{1 0 0 / 7 5 \%}$ \\
$\mathbf{0 . 5 0 0 / 0 . 0 5 0}$ & $0.500 / 0.043$ & $0.500 / 0.046$ & $0.500 / 0.042$ & $\mathbf{1 0 0 / 8 7 \%}$ \\
$\mathbf{1 . 0 0 / 0 . 1 0 0}$ & $1.00 / 0.080$ & $1.00 / 0.083$ & $0.980 / 0.088$ & $\mathbf{9 9 / 8 4 \%}$ \\
$\mathbf{5 . 0 0 / 0 . 5 0 0}$ & $5.00 / 0.338$ & $5.00 / 0.369$ & $4.92 / 0.401$ & $\mathbf{9 9 / 7 4 \%}$ \\
\hline
\end{tabular}

Table 6

HFE-7100@ NVR / S-316® HC - NASA/JSC Methodology

\begin{tabular}{|ccccc|}
\hline HFE 7100®/S-316® & \multicolumn{5}{c|}{ NVR/HC Recovery: JSC Method } \\
\hline Soil: FC/HC (mg) & Replicate 1 & Replicate 2 & Replicate 3 & Avg. \% Recovery \\
& & & & \\
$\mathbf{0 . 2 0 0 / 0 . 0 2 0}$ & $0.200 / 0.018$ & $0.200 / 0.015$ & $0.200 / 0.017$ & $\mathbf{1 0 0 / 8 3 \%}$ \\
$\mathbf{0 . 5 0 0 / 0 . 0 5 0}$ & $0.490 / 0.050$ & $0.500 / 0.047$ & $0.500 / 0.043$ & $\mathbf{9 9 / 9 3 \%}$ \\
$\mathbf{1 . 0 0 / 0 . 1 0 0}$ & $0.970 / 0.081$ & $1.00 / 0.090$ & $1.00 / 0.083$ & $\mathbf{9 9 / 8 5 \%}$ \\
$\mathbf{5 . 0 0 / 0 . 5 0 0}$ & $4.77 / 0.369$ & $4.62 / 0.371$ & $4.99 / 0.439$ & $\mathbf{9 6 / 7 9 \%}$ \\
\hline
\end{tabular}

\section{Discussion}

As previously discussed, Freon-113® is used as a sampling solvent at NASA/JSC for EMU (extravehicular Mobility Unit) SOP (Secondary Oxygen Pack) oxygen testing Cold Traps utilized at the USA (United Space Alliance) Houston facility. Similar testing occurs at the HSWL (Hamilton Sundstrand Windsor Locks) facility. A NASA Executive Order banned the procurement of all ODS (ozone depleting substances), including Freon-113® by the end of 2009. HSWL was directed to evaluate and certify a replacement for Freon-113®for the Cold Trap sampling process.

A number of people from pertinent disciplines (chemistry, test engineering, materials \& processes, environmental health and safety and project engineering) at HSWL, HSMS, NASA/JSC, NASA/WSTF and USA took part in the development of a Test Plan to evaluate replacements for Freon-113® Cold Trap sampling. A Test Plan Flow Chart was developed (see Diagram 1) to facilitate the activities associated with this effort.

Preliminary work focused on the development of a soiling model to represent contaminates observed in Cold Traps on a routine basis. Five alternate solvents were initially selected and underwent a preliminary evaluation of various criteria to down-select to two replacement approaches that were to undergo more detailed soil challenge testing.

It became apparent after the exercise summarized in Table 2 that no single candidate replacement solvent fulfilled all of the requirements expressed in the selection criteria. The best option appeared to be to utilize a dual solvent approach, HFE-7100® for the Cold Trap flush and NVR determination role, and S-316® to reconstitute the NVR for subsequent HC determination via FTIR. Two approaches to this dual solvent approach were targeted for full evaluation.

Option \#1, which was fully tested as described in this paper, consisted of a "nominal" Cold Trap flush with HFE-7100® utilizing the same flush methodology utilized by NASA/JSC (the more manually oriented approach) and HSWL (the more automated approach) was chosen as the primary approach. After collection of HFE-7100® 
from the Cold Trap, it is boiled down for an NVR determination. After NVR determination, the resultant residue was thereafter reconstituted with S-316® for subsequent HC determination via FTIR.

Freon 113® was found to recover $90-100 \%$ of total NVR and $83-100 \%$ of HC from a Cold Trap, see tables $2 \&$ 3. HFE-7100® being used solely as a solvent to remove NVR was found to recover $96-100 \%$ of NVR from a Cold Trap, see tables 4, 5 \& 6 . S-316 solvent being used solely as a reconstitution solvent for $\mathrm{HC}$ analysis was found to recover $74-93 \%$ of $\mathrm{HC}$ from a Cold Trap, see tables $5 \& 6$. This data is comparable to the Freon 113® data and thus it was deemed that the HFE-7100®/S-316® solvent pair is the recommended alternative approach for Cold Trap NVR and HC analysis.

\section{Conclusion}

HFE-7100® (a 3M fluorinated ether) was found to be an adequate replacement for Freon-113® as a solvent to remove and measure the non-volatile residue collected in a Cold Trap during oxygen testing. S-316® (a Horiba Instruments Inc. high molecular weight, non-ODS chlorofluorocarbon) was found to be an adequate replacement for Freon-113 $B$ as a solvent to reconstitute non-volatile residue removed from a Cold Trap during oxygen testing for subsequent HC (hydrocarbon) analysis via FTIR (Fourier Transform Infrared Spectroscopy). 